\title{
HARI FARMASIS SEDUNIA: PENYULUHAN INFORMASI OBAT DAN PEMBAGIAN MASKER GRATIS DI KAMPUNG SERAYA BATU AMPAR BATAM
}

\section{World Pharmacists Day: Drug Information Services and Free Mask Distribution in Seraya Village, Batu Ampar, Batam City}

\section{Delladari Mayefis*}

Sri Hainil

Hidayati

Stikes Mitra Bunda Persada,

Batam, Kepulauan Riau, Indonesia

*email: dellamayefis@gmail.com

\section{Kata Kunci:}

World Pharmacist Days

Pembagian Masker

Pelayanan Informasi Obat

Farmasi

\section{Keywords:}

World Pharmacists Days

Distribution of masks

Drug Information services

Pharmacy

\begin{abstract}
Abstrak
World Pharmacists day merupakan acara tahunan memperingati hari farmasis sedunia. Salah satu bentuk partisipasi kami prodi Sarjana Farmasi STIKes Mitra Bunda Persada Batam dalam memperingati hari farmasis sedunia ini adalah dengan mengadakan penyuluhan informasi obat sekaligus pembagian masker gratis bagi warga di kampung Seraya Batu Ampar. Pembagian masker gratis ini dikarenakan pada beberapa bulan belakangan ini telah terjadi kebakaran hutan yang mengakibatkan polusi udara di Kota Batam. Acara World Pharmacist Day ini diselenggarakan pada bulan September 2015 dengan Pelayanan Informasi Obat bagi warga sekitar dan pembagian masker gratis bagi pengendara di jalanan sekitar kampung seraya. Acara dimulai pada pagi hari yang dimulai dari tanya jawab warga tentang obat yang mereka gunakan kemudian dilanjutkan dengan pembagian masker. Acara ini mendapat sambutan yang sangat baik bagi warga sekitar karena sangat jarang sekali acara seperti ini dilakukan. Kami Prodi Farmasi sangat antusias untuk dapat memberikan pengabdian kepada masyarakat.
\end{abstract}

\begin{abstract}
World Pharmacists day is an annual event to commemorate World Pharmacist Day. One form of our participation in the Bachelor of Pharmacy STIKes study program Mitra Bunda Persada Batam in celebrating the World Pharmacist Day is to hold information on drug information as well as free mask distribution for residents in Seraya Batu Ampar village. This free mask distribution is because in recent months there have been forest fires that have caused air pollution in Batam City. The World Pharmacist Day program was held in September 2015 with Drug Information Services for residents and free mask distribution for motorists on the streets around the village while. The program began in the morning, which started with a question and answers from the residents about the drugs they were using, then continued with the distribution of masks. This event was very well received by the residents because it was scarce for an event like this to be done. Our Pharmacy Study Program is very enthusiastic about being able to provide community service.
\end{abstract}

(C) 2019 The Authors. Published by Institute for Research and Community Services Universitas Muhammadiyah Palangkaraya. This is Open Access article under the CC-BY-SA License (http://creativecommons.org/licenses/by-sa/4.0/). DOI: https://doi.org//0.33084/pengabdianmu.v4il .686.

\section{PENDAHULUAN}

Praktek kefarmasian sekarang ini telah mengalami perubahan paradigma dari drug oriented menjadi patient oriented. Dalam hal ini Apoteker memegang tanggung jawab baru untuk membantu perawatan pasien sampai sembuh (Tahir et al., 20I5). Selain itu, Apoteker dapat dijadikan rekomendasi dalam meningkatkan kesehatan masyarakat khususnya mengenai self medication. Perubahan paradigma inilah yang belum diketahui masyarakat (Rustanti \& Kusuma, 20|4). Pada umumnya masyarakat berpikir bahwa Apoteker adalah seseorang yang hanya bekerja menjaga apotek tanpa diketahui Apoteker sebenarnya memegang peranan setiap rantai akses untuk masyarakat sampai bisa mendapatkan obat (Rachmandini et al., 20I I).

Peran Apoteker sekarang sangat bervariasi mulai dari meracik obat, melakukan distribusi obat sampai pengontrolan obat pada pasien. Lapangan pekerjaan farmasi sebenarnya sangat luas tidak hanya sebatas di apotek seperti pemikiran banyak orang. Seorang Apoteker dapat bekerja di rumah sakit, puskesmas, balai pengobatan, industri farmasi, pemerintah, dan lain-lain. 
Selain itu Apoteker dapat dijadikan rekomendasi dalam meningkatkan kesadaran masyarakat terhadap pengobatan yang rasional (Yati et al., 2018; Nazer \& Tuffaha, 2017).

International Pharmaceutical Federation dalam kongres internasionalnya di Istanbul beberapa tahun yang lalu telah menetapkan bahwa setiap tanggal 25 September akan jatuh sebagai Hari Farmasi Sedunia atau World Pharmacist Day. Walaupun telah ditetapkan sebagai Hari Farmasi Sedunia, banyak masyarakat bahkan tenaga kesehatan lain yang tidak tahu. Hal ini disebabkan karena kurangnya pengenalan tentang dunia farmasi kepada masyarakat luas khususnya di Kota Batam. Pemikiran yang sempit tentang farmasi inilah yang melatarbelakangi kegiatan ini, dimana pelaksanaan kegiatan ini dapat membuka wawasan masyarakat luas tentang farmasi.

Selain itu pada saat bersamaan, beberapa tahun belakangan selalu terjadi polusi udara yang diakibatkan oleh adanya kebakaran hutan yang sangat parah di daerah Riau sekitarnya. Polusi ini sampai ke Kota Batam, bahkan ke Singapura. Pada saat ini masyarakat sangat membutuhkan masker untuk menghindari penyakit saluran pernafasan. Salah satu bentuk pengabdian kami prodi Farmasi kepada masyarakat adalah membagikan masker bagi warga dan pengendara di jalanan sekitaran kampong seraya. Hal inilah yang mendasari tema World Pharmacist Days kali ini yaitu pembagian masker gratis sebagai perlindungan diri dari polusi udara dan pencegahan penyakit saluran pernafasan sekaligus pelayanan informasi obat.

\section{METODOLOGI}

Tahap persiapan dari kegiatan ini adalah persiapan instrument untuk pemeriksaan cek gula darah dan tekanan darah secara gratis. Tempat dan alat-alat lainnya disiapkan oleh dosen koordinator dan anggota yang terdiri dari:

I. Alat Mengukur Kadar Gula darah dan Tekanan darah
2. Persiapan jumlah masker dan vitamin $C$ untuk dibagikan secara gratis

3. Persiapan wilayah pembagian masker dan vitamin $C$

4. Persiapan meja dan tenda untuk pemberian informasi obat serta bagaimana alur kerjanya

5. Persiapan Buku petunjuk sebagai referensi yang menjelaskan cara-cara penilaian kadar gula darah dan pelayanan informasi obat yang diberikan.

Acara dimulai pada pukul 08.00 pada tanggal 26 September 2015 bertepatan dengan hari Farmasi Sedunia tanggal 25 September 2015, sesuai dengan rencana. Jumlah Peserta yang bertanya dan konsultasi informasi obat sebanyak 35 orang dan mahasiswa yang aktif sebanyak 85 orang mahasiswa farmasi. Peran mahasiswa sudah sesuai dengan uraian tugas yang ditetapkan. Adapun uraian kegiatan di lapangan selama survey berlangsung adalah sebagai berikut:

I. Memberikan informasi dan konseling penggunaan obat yang banyak digunakan oleh masyarakat.

2. Pembagian vitamin c dan masker secara gratis

3. Pengecekan gula darah gratis

4. Pengenalan terhadap ragam "merchandise" SI Farmasi Stikes Mitra Bunda Persada seperti: gantungan kunci, baju kaos, stiker, dan lain-lain.

\section{HASIL DAN PEMBAHASAN}

Pada hari ini, Sabtu, tanggal 26 September 2015 telah dilaksanakan kegiatan World Pharmacist day di Wilayah Kerja Stikes Mitra Bunda Persada Batam. Program Pengabdian Masyarakat Dosen Stikes Mitra Bunda Persada Batam dengan tema "Jika ragu tentang obatobatan, tanyakan kepada Farmasis Anda”. Kegiatan tersebut diikuti oleh 35 Orang masyarakat dan 85 mahasiswa farmasi yang melakukan pembagian masker gratis dan vitamin $\mathrm{C}$.

Tujuan dari Kegiatan ini adalah :

I. Mengenalkan kepada masyarakat tentang farmasi dan peranannya dalam dunia kesehatan. 
2. Memberikan informasi obat dan konsultasi tentang bagaimana cara menggunakan dan mencegah masyarakat dan profesi kesehatan lainnya dalam penyalahgunaan obat.

3. Membantu masyarakat dalam mencegah penyakit infeksi saluran nafas akibat adanya polusi udara karena kebakaran hutan

Adapun Susunan Acara dari kegiatan ini adalah :

I. Memberikan informasi dan konseling penggunaan obat secara langsung yang banyak digunakan oleh masyarakat.

2. Pembagian vitamin c dan masker secara gratis

3. Pengecekan gula darah gratis

4. Pengenalan terhadap ragam "merchandise" SI Farmasi Stikes Mitra Bunda Persada seperti: gantungan kunci, baju kaos, stiker, dll.

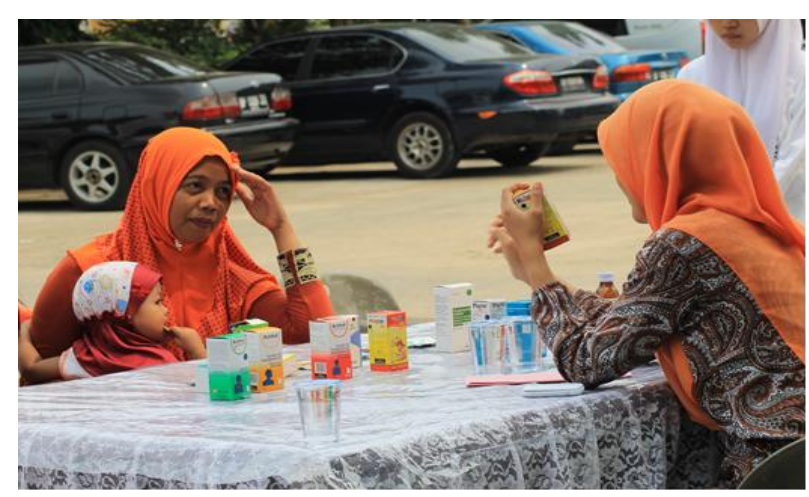

Gambar I. Pelayanan Informasi Obat

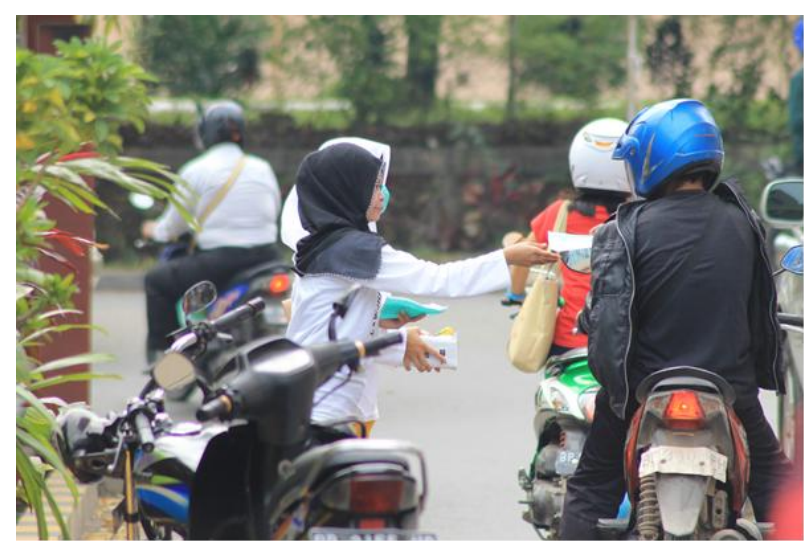

Gambar 2. Pembagian masker bagi pengendara motor

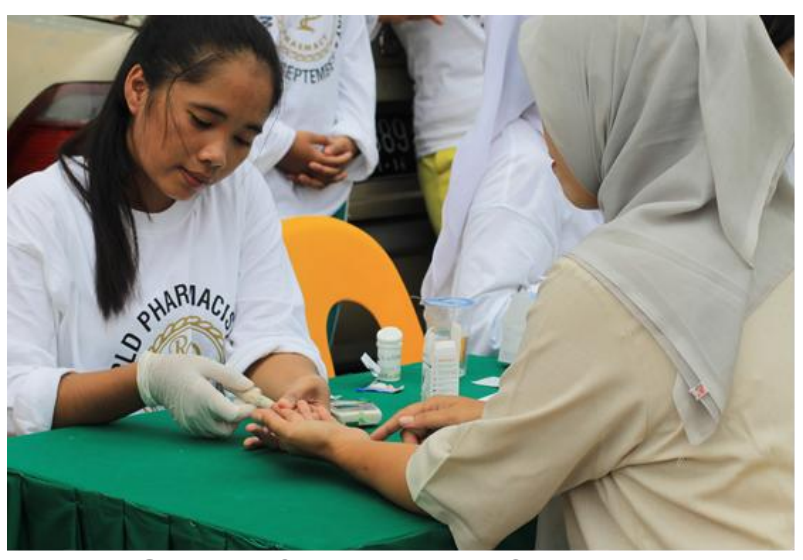

Gambar 3. Pemeriksaan Gula darah

\section{KESIMPULAN}

Telah dilaksanakan kegiatan World Pharmacist day di Wilayah Kerja Stikes Mitra Bunda Persada Batam yaitu daerah kampong Seraya Batu Ampar. Program Pengabdian Masyarakat Dosen Stikes Mitra Bunda Persada Batam dengan tema "Jika ragu tentang obatobatan, tanyakan kepada Farmasis Anda”. Kegiatan tersebut diikuti oleh 35 Orang masyarakat dan 85 mahasiswa farmasi yang melakukan pembagian masker gratis dan vitamin $\mathrm{C}$.

\section{UCAPAN TERIMA KASIH}

Penulis mengucapkan terimakasih kepada kepada Ketua Stikes dan para dosen Mitra Bunda Persada Batam, Ketua RT/RW Kampung Seraya Batu Ampar, Mahasiswa/l yang sudah terlibat dan antusias masyarakat Kampung Seraya meyaksikan acara kami.

\section{REFERENSI}

Nazer, L.H. \& Tuffaha, H. 2017. Health Care and Pharmacy Practice in Jordan. The Canadian Journal of Hospital Pharmacy. 70(2): I50-I55.

Rachmandini, A.A., Sampurno, \& Purnomo, A. $20 \mathrm{II}$. Peran Ikatan Apoteker Indonesia (IAI) dalam Upaya Pelaksanaan Standar Pelayanan Kefarmasian di Apotek Di Daerah Istimewa Yogyakarta. Jurnal Manajemen dan Pelayanan Farmasi. I (2): I03-I I0. 
Rustanti, Y.A. \& Kusuma, A.M. 2014. Pengetahuan, Sikap dan Perilaku Apoteker dalam Pekerjaan Kefarmasian di Rumah Sakit di Wilayah Karesidenan Banyumas. Sainteks. I I (2): I2- I8.

Tahir, M.T., Yulistiani, \& Amiruddin, R. 2015. Implementation of Pharmaceutical Care in Resolving Drug Problems in Type 2 Diabetes Mellitus. Folia Medica Indonesiana. 5 I(2):8085.

Yati, K., Hariyanti, Dwitiyanti, \& Lestari, P.M. 2018. Pelatihan Pengelolaan Obat yang Tepat dan Benar di UKS SekolahSekolah Muhammadiyah Wilayah DKI Jakarta. Jurnal Solma. 7(I):42-49. 